\title{
THE PERCEPTION AND USING OF ICT IN THE DIFFERENT AGE GROUPS
}

\section{Milan KUBIATKO}

\begin{abstract}
The using of information and communication technologies (ICT) is typical for the recent time in the all aspects of human life. Every age group is using ICT due to different purposes and the difference is possible to observe in the time length spent by using of ICT. On the basis of the mentioned fact, there is the dividing of people into the different groups according to using of ICT. One of the dividing is determining the group called "Generation Y" or "Millennial Generation". This generation comprises people born in 1981 and later. The Generation Y is different in the using of ICT and it has got different perception of ICT in the comparison with older people. The main aim of the investigation was to compare using and perception of ICT, with the focusing on the using and perception of Internet, by two groups of respondents. First group was created by respondents belonging to Generation $\mathrm{Y}$ and the second group was created by older respondents, which was called Generation X. The sample size was created by 266 respondents of different work environment, there were presented college students, academic staff, high school students. The Generation Y comprised of 200 respondents, the age range was between $17-57$ years. As the research tool was a questionnaire with 64 Likert type items focusing on the perception of ICT and 9 items focusing on the using of ICT. The methods of inductive statistic (chi-square for independent samples and t-test for independent samples) were used for the determination of differences. Also, the methods of multidimensional statistic were used for the determination of reliability (Cronbach's alpha) and validity (explorative factor analysis).
\end{abstract}

Key words: questionnaire, Generation $\mathrm{Y}$ and $\mathrm{X}$, information and communication technologies, quantitative methodology

\section{VNÍMANIE A POUŽÍVANIE ICT V RÔZNYCH VEKOVÝCH SKUPINÁCH}

Resumé: Pre súčasnú dobu je typické využívanie informačných a komunikačných technológií (ICT) vo všetkých aspektoch l'udského života. Každá veková skupina využíva ICT kvôli iným účelom a rozdiel je možné sledovat' aj v čase strávenom používaním ICT. Na základe uvedených skutočností dochádza k deleniu l'udí do rôznych skupín podl'a používania ICT. Jedno z používaných delení

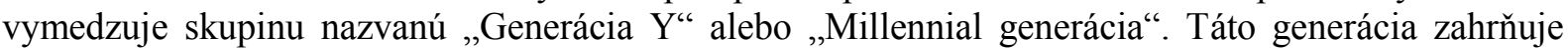
l'udí narodených v roku 1981 a neskôr. Generácia Y sa vyznačuje určitými odlišnost'ami vo využívaní a vo vzt'ahu k ICT v porovnaní so staršími l'ud’mi. Vo výskumnom šetrení bolo hlavným ciel'om porovnat' používanie a vnímanie ICT, pričom zameranie bolo hlavne na internet, dvoma skupinami respondentov. Prvú vytvárali respondenti patriaci do Generácie Y a druhú starší respondenti, ktorá bola pracovne nazvaná Generácia X. Výskumnú vzorku vytváralo 266 respondentov rôzneho pracovného zaradenia, čast' $\mathrm{z}$ nich bola tvorená vysokoškolskými študentmi, akademickými pracovníkmi, či učitel'mi zo stredných škôl. Do generácie Y bolo zaradených 200 respondentov, vek sa pohyboval v rozmedzí 17 až 57 rokov. Ako výskumný nástroj bol použitý dotazník so 64 položkami Likertovho typu zameranými na vnímanie ICT, s 9 položkami zameranými na používanie ICT. Na stanovenie rozdielov medzi vo vzt'ahu $\mathrm{k}$ ICT a v použivaní ICT boli použité metódy induktívnej štatistiky (chí-kvadrát test pre nezávislé výbery a t-test pre nezávislé výbery). Okrem uvedených metód boli použité aj metódy viacrozmernej štatistiky, ktoré slúžili na stanovenie reliability (Cronbachovo alfa) a validity výskumného nástroja (exploratívna faktorová analýza).

Klíčová slova: dotazník; generácia $\mathrm{Y}$ a X; informačné a komunikačné technológie; kvantitatívne spracovanie dát

\section{1 Úvod}

Generácia Y nie je používaným pojmom len vo vzdelávacom procese, ale tiež vo všetkých odvetviach l'udskej činnosti. S touto generáciou je úzko spätý aj ekonomický svet [1]. Pre generáciu $Y$ je možné nájst' väčšie množstvo 
synoným, napríklad net generácia, generácia nového tisícročia (millennial generation) a d’alšie. Ako jeden z prvých, kto oficiálne definuje pojem generácia $\mathrm{Y}$ je Tapscott vo svojej práci z roku 1997 [2]. Jeho ponímanie daného pojmu bolo nasledované d’alšími, napríklad [3] v podstate podobne ako Tapscott rozlišuje len medzi generáciou $\mathrm{Y}$, ktorá vníma informačné a komunikačné technológie v pozitívnom význame, v porovnaní s druhou skupinou nazvanou digitálni imigranti. Postupom času definícia generácie Y naberala jasnejšie kontúry. Pre generáciu $Y$ je typické, že vyrastá $\mathrm{v}$ globalizovanej spoločnosti, kde nedostatok času a priestoru sa prekonáva d’alším rozvojom a používaním informačných a komunikačných technológii; je to technologická generácia, ktorá chápe počítače (desktopy aj laptopy), e-maily, internet so všetkými ich možnost’ami za bežnú súčast' života, niektorí autori uvádzajú, že až nevyhnutnú. Pre generáciu $\mathrm{Y}$ je typickým pojmom tzv. glokalizácia (spojenie globalizácie a lokalizácie). Jedinci patriaci do uvedenej generácie ostávajú dlhšie študovat', aby boli vyzbrojení na trh práce, ktorý vyžaduje čoraz viac špecializované a flexibilné pracovné sily. Preživajú neistotu ohl'adne zamestnania, celoživotné zamestnania sú pre nich neznámym pojmom. Pre týchto l'udí je typická preinformovanost', priepast' medzi tým, čo vedia a tým, čomu rozumejú. Často vytvárajú tzv. ekomunity, kde nachádzajú podporu rovnakozmýšlajúcich. Typickým javom pozorovaným u generácie $\mathrm{Y}$ je vykonávanie viacerých vecí naraz, popri práci dokážu telefonovat', počúvat' hudbu, sledovat' televíziu, byt' pripojený k rôznym sociálnym siet’am, k rôznym chatovacím programom, prípadne hrat' aj on-line hru. Čo sa týka práce, majú radi flexibilnú pracovnú dobu, a tiež rôzne pracovné prostredia, dokážu pracovat' nielen v kancelárii, ale aj $\mathrm{v}$ domácom prostredí, prípadne $\mathrm{v}$ reštauračnom zariadení, cestou do práce, či z práce, ale aj cez víkendy, či v noci. Autori pri charakteristike uvedenej skupiny píšu aj o jej negatívach. Do popredia sa dostáva najmä oslabenie porozumenia absolútnej morálky a neuznávanie rodiny $[4,5,6,7,8]$.

Pri definovaní generácie $\mathrm{Y}$ dochádza často k problému stanovenia jej hranice. Niektorí autori uvádzajú, že do danej generácie patria jedinci narodení po roku 1980 [9], či 1982 [10]. Ale asi najčastejšie publikovaným rokom je rok 1981, ktorí označuje jedincov patriacich do uvedenej generácie, čiže narodených v roku 1981 a neskôr
$[11,12]$. Pred generáciou $\mathrm{Y}$ bola generácia $\mathrm{X}$ (generácia next, digital generation, MTV generation) (1963 - 1980), rozpätie rokov môže varírovat' v závislosti od autora. Pre túto generáciu je typické, že je ovplyvnená predošlou generáciou. Je možné sa stretnút' aj s označením, že sa jedná o generáciu detí s klúčikom na krku, ktorí boli svedkom rozvodu svojich rodičov, rozšírenia AIDS vo vlastnej generácii a čelia narastajúcej nezamestnanosti, čo je možno spôsobené aj ich nie úplnou znalost'ou informačných a komunikačných technológií a tým aj zaostávania $\mathrm{v}$ ich adekvátnom používaní v porovnaní s generáciou Y. Zastihol ich prudký rozvoj a rozmach informačných a komunikačných technológií, ktorému nie vždy dokážu čelit' [13]. Pomenované sú aj predošlé generácie (generácia svetových vojen, generácia stavitel'ov a tzv. baby-boomers) [13]. V porovnaní s generáciou Y sa často dostávajú do porovnania najmä kvôli ich vzt'ahu a prístupu k informačným a komunikačným technológiám. Do porovnania sa dostáva najmä generácia $\mathrm{X}$, prípadne babyboomers.

Výskumné práce sa orientujú bud' na to, ako vnímajú jedinci patriaci do generácie $\mathrm{Y}$ informačné a komunikačné technológie, prípadne sú porovnávané generácie $\mathrm{X}$ a generácie $\mathrm{Y}$. Napríklad vo výskumnej práci Borgesa a kol [11] boli porovnávané práve tieto dve generácie prostredníctvom dotazníka. Autori uvádzajú, že ich výsledky sú v zhode s vnímaním oboch generácií. Twenge [14] vo svojej zhrňujúcej štúdii uvádza, že l'udia patriaci do generácie $\mathrm{Y}$ dokážu viac profitovat' $\mathrm{z}$ informácii, ktoré sú $\mathrm{v}$ elektronickej podobe, tiež moderné technológie viac používajú vo svojej práci, či štúdiu. $\mathrm{V}$ porovnaní s inými generáciami viac dôverujú informáciám poskytovaným $\mathrm{v}$ internetovom prostredí, dokážu vykonávat' popri práci aj d’alšie činnosti. Z d'alších vecí autor ešte uvádza, napríklad majú radšej text členený na kratšie segmenty, ako keby mali pracovat' s jedným dlhým textom. Výskumné šetrenie Djamasbiho a kol. [15] na meranie pozornosti pri poskytovaní informácií. Autori uvádzajú, že jedinci patriaci do generácie Y majú radšej krátke úseky textu, ktoré sú obohatené interaktívnymi prvkami. Jones a Hosein [16] pri porovnaní mladších a starších respondentov uviedli, že jedinci narodení po roku 1981 vykazujú väčšiu sociálnu zaangažovanost' než starší jedinci, ale len na sociálnych siet'ach, viac preferujú používanie chatovacích programov v porovnaní so staršími a podobne ako $\mathrm{v}$ predchádzajúcich výskumných 
šetreniach autori zistili, že mladší študenti radšej pracujú s kratšími textami.

Dôvodom výskumného šetrenia je fakt, že výskum podobného charakteru sa v podmienkach Slovenska, či Českej republiky neuskutočnil. Pri tvorbe výskumného nástroja bola snaha sa neodklonit' od doteraz publikovaných prác a vytvorit' výskumný nástroj, ktorý by svojim obsahom postihoval čo najviac aspektov odlišujúcich generáciu Y od l’udí nepatriacich do tejto generácie. Vo výsledkovej časti sú predstavené rozdiely medzi dvoma generáciami, prípadnými d'alšími analýzami by bola výsledková čast' predimenzovaná, preto ostatné výsledky sú plánované $\mathrm{v}$ d'alších publikačných výstupoch týkajúcich sa danej problematiky.

\section{Metodika}

Hlavným ciel'om bolo porovnat' používanie informačných a komunikačných technológií a ich vnímanie medzi respondentmi patriacimi do generácie Y a staršími respondentmi. Tomuto porovnaniu predchádzalo vytvorenie a overenie výskumného nástroja zameraného na používanie a postoje $\mathrm{k}$ ICT.

\section{Výskumná vzorka}

Výskumnú vzorku tvorilo 266 respondentov zo Slovenska a Českej republiky. Respondenti boli z rôzneho prostredia, najpočetnejšiu čast' vytvárali respondenti $\mathrm{z}$ akademického prostredia (študenti, vysokoškolskí učitelia), d’alej to boli aj učitelia zo základných, či stredných škôl. A do výskumnej vzorky boli zaradení aj respondenti z iného pracovného prostredia. Respondenti boli rozdelení do dvoch skupín, generáciu Y vytvárali respondenti narodení roku 1981 a neskôr. Druhá skupina respondentov bola tvorená staršími jedincami, síce tu boli zaradení aj respondenti narodení skôr ako v roku 1963, ale týchto respondentov bolo vel'mi malé množstvo, tak táto skupina bola označená ako generácia $X$. $\mathrm{Z}$ uvedeného počtu respondentov do generácie $\mathrm{Y}$ ich patrilo 200 a do druhej skupiny zvyšok. Priemerný vek skúmaných osôb bol 26,36 (SD = 10,39). Najmladší respondent mal 17 a najstarší 57 rokov.

\section{Výskumný nástroj}

Ako výskumný nástroj slúžil dotazník vlastnej konštrukcie pozostávajúci z troch hlavných častí. Prvú čast' vytvárali demografické položky (gender, vek a bydlisko). Druhú čast' tvorili položky $(\mathrm{n}=9)$ zamerané na používanie informačných a komunikačných technológií. Čast' z nich bola dichotomická (napr. Využivam internetbanking - áno / nie) a čast’ sa týkala frekvencie používania (napr. Internet používam na chatovanie), meranej na 4-stupňovej škále (nikdy - v priemere raz za mesiac - v priemere raz za týždeň - takmer každý deň). Možnosti „nikdy“" sa priradila bodová hodnota 1 a možnosti „takmer každý deň“ “4. Tretiu čast' tvorilo 64 5bodových položiek Likertovho typu (úplne nesúhlasím-....-úplne súhlasím). Položky boli zamerané na rôzne aspekty ICT, napríklad na vzt'ah respondentov $\mathrm{k}$ chatovacím programom, $\mathrm{k}$ sociálnym siet’am, na st’ahovanie filmov, či hudby. Položky v dotazníku boli prezentované v pozitívnej $(\mathrm{n}=46)$ aj negatívnej $(\mathrm{n}=18)$ podobe. Pri pozitívnych položkách bol najviac negatívnej možnosti prisúdený 1 bod a najviac pozitívnej bolo priradených 5 bodov. Negatívne položky boli kódované opačne. Celkové skóre ukázalo vzt'ah $\mathrm{k}$ ICT. Ak sa skóre pohybovalo $\mathrm{v}$ rozsahu $<2,75 ; 3,25>$ tak je možné hovorit' o neutrálnom vzt’ahu, ak bolo nižšie ako 2,75 je možné hovorit' o negatívnom vzt'ahu, a ak bolo vyššie ako 3,25 je možné označit' vnímanie ICT za pozitívne. Jednou z možností stanovenia validity je posúdenie výskumného nástroja odborníkmi. Po obdŕžaní ich pripomienok boli návrhy na úpravu zapracované do finálnej verzie výskumného nástroja. Na stanovenie validity tretej časti dotazníka bola použitá exploratívna faktorová analýza (vid’ Analýza dát).

\section{Administrácia výskumného nástroja}

Výskumný nástroj bol distribuovaný medzi respondentov dvoma spôsobmi. Prvým bolo rozdanie papierovej verzie medzi poslucháčov vysokých škôl na prednáške. Druhý spôsob bol elektronickou formou, vtedy bol respondentom zaslaný webový odkaz, po ktorého odkliknutí sa im zobrazil dotazník. Všetci respondenti boli informovaní o anonymite výskumného nástroja, a vyplňovanie nepresiahlo viac ako 20 minút.

\section{Analýza dát}

Po prekódovaní získaných dát do číselnej podoby z tretej časti dotazníku bola aplikovaná exploratívna faktorová analýza s Varimax rotáciou. Pred jej samotným použitím boli na dáta aplikované testy, ktorých hodnoty umožnili použitie faktorovej analýzy $(\mathrm{KMO}=0,68$; Bartlettov test sféricity $\left.\chi^{2}=4774,81 ; p<0,001\right)$. Faktorová analýza rozdelila položky z tretej časti dotazníka do siedmych kategórií: 1 . Práca a ICT (15 položiek); 2. Internet ako zdroj informácií (6 položiek); 3. Sociálne siete (14 položiek); 4. Bezpečnost' internetu (13 položiek); 5. Ťažkosti s používaním internetu (5 položiek); 6 . Dôležitost' internetu (5 položiek); 7. Ďalšie média a internet (6 položiek). Hraničná hodnota 
faktorového skóre bola 0,30. Výsledky faktorovej analýzy sú uvedené v prílohe 1 .

Na určenie spol’ahlivosti výskumného nástroja bol použitý koeficient Cronbachovo alfa $(\alpha)$. Jeho hodnota pre tretiu čast' dotazníka $(\alpha=0,83)$ indikuje vysokú spol'ahlivost'. Hodnota Cronbachovho alfa pre jednotlivé kategórie sa pohybovala v rozmedzí od 0,51 do 0,66 , čo je dostačujúce hodnota pre určenie spol'ahlivosti jednotlivých kategórií [17].

Pre štatistické vyhodnotenie bol použitý t-test pre nezávislé výbery, ktorý bol aplikovaný pri porovnaní vnímania ICT medzi generáciou $\mathrm{Y}$ a generáciou $\mathrm{X}$ a tiež pri frekvencii používania rôznych ICT aplikácii. Pri položkách, ktoré boli dichotomické a boli zamerané na používanie ICT bol aplikovaný chí-kvadrát test nezávislosti.

\section{Výsledky}

Celkové skóre časti zameranej na vnímanie informačných a komunikačných technológií bolo $\mathrm{x}=3,02(\mathrm{SD}=0,32)$, čo indikuje neutrálne vnímanie ICT. V grafe 1 je zobrazená distribúcia skóre za jednotlivé dimenzie. Najnižšie skóre bolo zistené pri kategórii „Sociálne siete“, táto kategória spolu s kategóriou „Práca a ICT“ boli vnímané negatívne. Najvyššie skóre bolo zaznamenané v kategórii „Bezpečnost' internetu“. Okrem tejto kategórie bola pozitívne ešte vnímaná kategória „Ťažkosti s používaním internetu“, ostatné kategórie dosahovali skóre, ktoré vypovedá o ich neutrálnom vnímaní.

Graf 1 Priemerné skóre za jednotlivé dimenzie

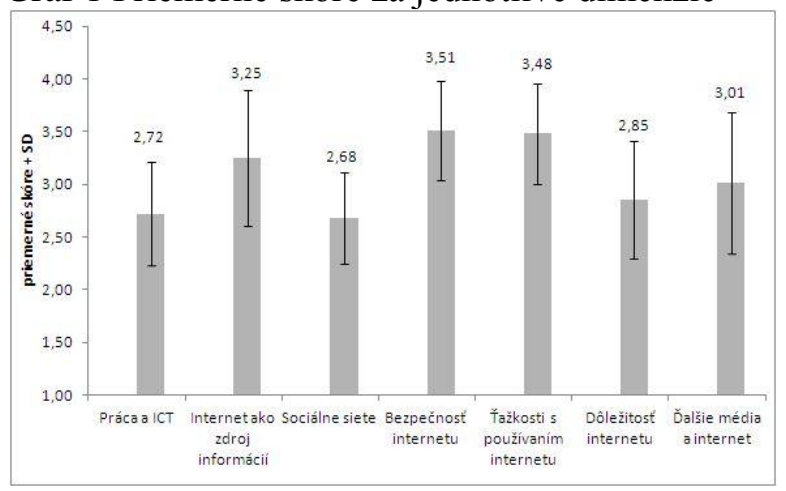

Generácia Y dosiahla pri hodnotení časti dotazníka zameraného na vnímanie informačných a komunikačných technológií významne vyššie skóre $(\mathrm{x}=3,04 ; \mathrm{SD}=0,33) \quad \mathrm{v}$ porovnaní $\mathrm{s}$ generáciou $\mathrm{X}(\mathrm{x}=2,93 ; \mathrm{SD}=0,28)(\mathrm{t}=2,51 ; \mathrm{p}$ $<0,05)$. Pri analýze jednotlivých kategórií bol zistený významný rozdiel u troch kategórií „Práca a ICT“, „Sociálne siete“ a „Ďalšie média a internet". Vo všetkých troch vyššie menovaných dimenziách dosiahli vyššie skóre respondenti patriaci do generácie $\mathrm{Y}$. V jednoduchosti povedané to znamená, že táto skupina respondentov pozitívnejšie vníma prepojenie informačných a komunikačných technológií s ich prácou, je pre nich viac prirodzené mat' zapnuté chatovacie programy, pracovat' $\mathrm{z}$ domu, používat' v pracovnej dobe súkromný mail a takisto aj naopak mimo pracovnej doby používat' pracovný mail. Viac-menej je očakávané, že mladší respondenti budú pozitívnejšie vnímat' sociálne siete a mat' $\mathrm{k}$ nim väčšiu dôveru, ako ich starší kolegovia. Čo sa týka poslednej kategórie, v ktorej zistený významný rozdiel mladší respondenti pozitívnejšie vnímajú fakt, že televízne vysielanie sa prenáša na internet a dokážu ho sledovat' aj mimo dobu jeho skutočného vysielania. Na grafe je možné vidiet' aj skutočnost', že v dvoch kategóriách dosiahli vyššie skóre starší respondenti. Jedná sa o zaujímavé zistenie, ked’že starší respondenti pozitívnejšie vnímajú internet ako zdroj informácií, čo znamená, že majú väššiu dôveru voči informáciám prezentovaných na internete a tiež majú menšie t’ažkosti s používaním internetu ako mladší respondenti.

Graf 2 Priemerné skóre za jednotlivé dimenzie s ohl'adom na generáciu

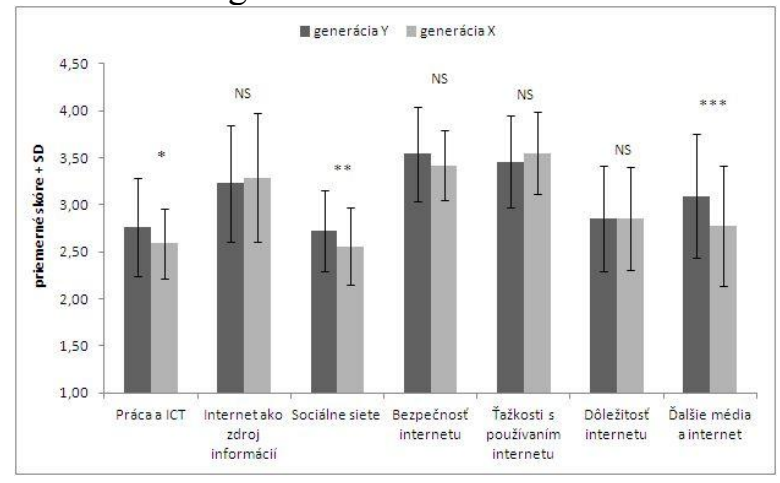

NS - nesignifikantný rozdiel

$* \mathrm{p}<0,05$

$* * \mathrm{p}<0,01$

$* * * \mathrm{p}<0,001$

Používanie ICT a internetu bolo merané viacerými spôsobmi. Prvým bolo určenie frekvencie používania jednotlivých možností, ktoré ponúka internetové prostredie. A ako je možné pozorovat' na grafe 3 generácia $Y$ dosahovala významne vyššie skóre v možnostiach „chatovanie“, „st’ahovanie hudby a filmov" a „hranie hier". Starší respondenti vdvoch možnostiach a to: „mailovanie“ a 
„vyhl'adávanie odborných informácií“. U ostatných možností nebol zistený významný rozdiel, skóre bolo zväčša vyrovnané. Z uvedených zistení vyplýva, že kým mladši respondenti preferujú aktivity, ktoré trvajú relatívne dlhší čas a slúžía v prevažnej miere na zábavu. A tiež, čo sa týka najmä chatovania uprednostňujú ak je odpoved', ktorú žiadajú rýchla, v porovnaní so staršími respondentmi, ktorí radšej napíšu dlhšiu informáciu do mailu a nečakajú pri tom na okamžitú odpoved'. A ak majú strávit' v internetovom prostredí dlhší čas, tak je to hlavne kvôli vyhl'adávaniu odborných informácií, ktoré slúžia k príprave na vyučovanie, či týkajúce sa ich práce.

Graf 3 Priemerné skóre za jednotlivé možnosti položky „Internet používam na tieto časti“.

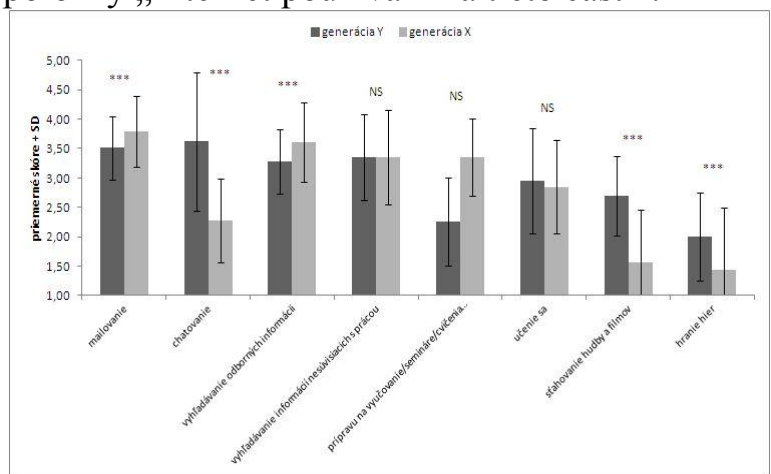

NS - nesignifikantný rozdiel

$* * * \mathrm{p}<0,001$

Používanie možností ktoré ponúkajú informačné a komunikačné technológie a internet boli získavané od respondentov prostredníctvom dichotomických odpovedí (áno / nie) a následne ich zastúpenie porovnávané prostredníctvom chíkvadrát testu. Generácia $Y$ používa na komunikáciu s kamarátmi významne vo väčšej miere chatovacie programy, ako sú napríklad Skype, ICQ v porovnaní s generáciou $\mathrm{X}\left(\chi^{2}=\right.$ 26,01; p < 0,001). Podobná situácia, je aj pri použivaní chatovacích programov pre pracovné účely, rozdiel bol opät' významný $\mathrm{v}$ prospech mladších respondentov $\left(\chi^{2}=6,89 ; \mathrm{p}<0,05\right)$. Štatisticky významný rozdiel v prospech mladších respondentov bol nájdený pri d'alšej položke, týkajúcej sa vlastníctva minimálne jedného konta na sociálnej sieti $\left(\chi^{2}=34,23\right.$; $p<$ $0,001)$. V d'alšej položke respondenti odpovedali, kol'ko času strávia na internete. Účastníci výskumného šetrenia mali 5 možností (graf 4) a bol zistený významný rozdiel vo výsledkoch $\left(\chi^{2}\right.$ $=21,45 ; \mathrm{p}<0,001)$. Detailnejšia analýza ukázala, že významný rozdiel bol len pri prvej možnosti.
Z grafu možno vyčitat', že starší respondenti trávia používaním internetu menej času.

Graf 4 Percentuálne vyhodnotenie odpovedí na položku „Na internete priemerne strávim (na jedno posedenie)“

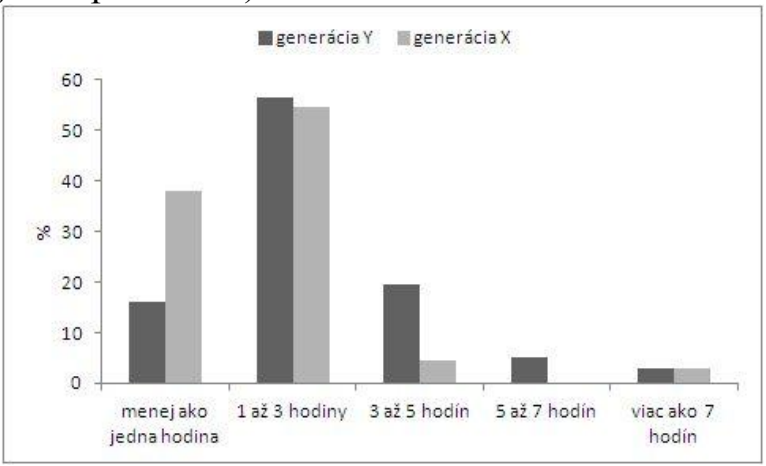

Internetové bankovníctvo majú viac v obl'ube starší respondenti $\left(\chi^{2}=8,41 ; \mathrm{p}<0,05\right)$. Na d'alšiu položku, ktorá bola v spojitosti s predošlou, respondenti odpovedali, či ich rodičia použivajú internetové bankovníctvo, tak mladší respondenti odpovedali častejšie kladne ako ich starší kolegovia $\left(\chi^{2}=43,62 ; p<0,001\right)$. Vo výsledkoch d’alších položiek už nebol zistený významný rozdiel: „Už som mal zavírený počítač“ $\left(\chi^{2}=0,46 ; p=0,49\right)$, "Už sa mi stalo, že som prišiel o všetky údaje v počítači " $\left(\chi^{2}=0,13\right.$; $\mathrm{p}=0,72)$ and "Používal som už internet aj $\mathrm{v}$ zahraničí " $\left(\chi^{2}=0,03 ; p=0,96\right)$.

\section{Diskusia a záver}

Jedným z hlavných ciel'ov výskumu bolo porovnat používania informačných a komunikačných technológií medzi generáciou Y a X. Druhým ciel'om bolo navrhnút' a overit' výskumný nástroj zameraný na vnímanie a používanie ICT. Súhrnne je možné rozdelit' výsledky do troch častí.

Ako prvým výrazným výsledkom je vytvorenie a overenie výskumného nástroja. Najmä postojová čast', ktorá bola aj najrozsiahlejšia, bola podrobená detailným analýzam. Exploratívna faktorová analýza bola použitá na zabezpečenie validity a rozdelila položky do siedmich kategórií. Výskumný nástroj je vol'ne prístupný pre iných záujemcov o danú problematiku.

Po druhé, vo výskumnom šetrení bolo zist'ované vnímanie informačných a komunikačných technológií respondentmi. Účastníci výskumu vykazovali neutrálne vnímanie ICT, po detailnejších analýzach bolo možné sledovat' pozitívne skóre $\mathrm{v}$ dvoch kategóriách „Bezpečnost' internetu“ a „Ťažkosti 
s používaním internetu“. Znamená to, že pre respondentov nebol problém použivat' internet a oni verili, že internet nie je náročný na používanie, ani pre deti, ani pre skôr narodených l'udí. Respondenti d'alej verili $\mathrm{v}$ bezpečnost' internetu, nemali problém s nakupovaním cez internet a problém im nerobilo ani používanie služieb ako je internetové bankovníctvo. Ďalej bolo zistené pozitívnejšie vnímanie sociálnych sietí generáciou Y. Respondenti spadajúci do tejto skupiny preferujú komunikáciu s inými práce cez sociálne siete. Uvedené zistenia sú v zhode aj s inými výskumnými šetreniami podobného charakteru, napríklad [18] poukazujú na fakt neoddelitel'nosti počítačov od života mladých l'udí, autori d’alej uvádzajú, že mladí l’udia trávia svoj vol'ný čas prevažne prihlásení na sociálnych sietach a chatovaním. Mladí l'udia preferujú komunikáciu práve cez vyššie zmienené možnosti, v porovnaní s komunikáciou tvárou v tvár. V našom výskume bolo zaujímavé zistenie, respondenti patriaci do $\mathrm{Y}$ generácie dosiahli významne vyššie skóre v dimenzii „Ďalšie média a internet“. Na základe daného faktu je možné povedat', že respondenti patriaci do Y generácie nemajú problém zamenit' sledovanie televízie alebo čítanie novín za ich používanie na internete. Podobné zistenie je možné nájst' v štúdii [19]. Generácia mladších l’udí dosiahla vyššie skóre v kategórii „Práca a ICT“, čo znamená, že nemajú problém vykonávat' svoju prácu v domácom prostredí, a tiež nemajú problém mat' popri práci zapnutý chatovací program, sledovat' zároveň televíziu a byt' pripojený k sociálnej sieti.

Posledným záverom vyplývajúcim $\mathrm{z}$ výsledkov bolo rozličné používanie ICT generáciou $\mathrm{Y}$ a generáciou $\mathrm{X}$. Generácia $\mathrm{X}$ používa internet viac na mailovanie a generácia $\mathrm{Y}$ viac na chatovanie. Mail pravdepodobne pre mladších respondentov neobsahuje tol'ko interaktívnych prvkov, aby ich mohol zaujat', a tiež podstatnú úlohu tu zohráva aj relatívne dlhá doba čakania na odpoved', ktorá je u chatu okamžitá (ak sú obe strany on-line). Celkovo povedané respondenti zaradení do generácie $\mathrm{Y}$ používajú internet a ICT viac nekonformne ako generácia $X$. Podobne o použivaní internetu a ICT uvádzajú aj [4] a niektoré $\mathrm{z}$ ich charakteristík generácie $\mathrm{Y}$ sú $\mathrm{v}$ zhode s našimi. Ako autori uvádzajú táto generácia l'udí používa internet a ICT inak ako staršia generácia, mladší l’udia sú viac závislí na ICT, je to pre nich prvotný zdroj a informácií, ICT je pre nich nástrojom na zdielanie získaných aj vlastných informácií.

Sumárne povedané, naše výskumné šetrenie ukázalo, že v podmienkach Českej republiky a Slovenska je možné vidiet' rozdiel v použivaní a vo vnímaní ICT medzi generáciou $\mathrm{X}$ a generáciou Y. Uvedené výskumné šetrenie obsahuje mnoho limitov, na ktoré je možné brat' ohl'ad pri d’alších výskumných šetreniach podobného typu, napríklad zahrnút do analýz d'alšie premenné, ktoré môžu vplývat' na používanie a vnímanie ICT (napr. bydlisko, gender), prípadne sa pokúsit' naviazat' medzinárodnú spoluprácu a porovnat' výsledky medzi viacerými štátmi, kde je pohl'ad a využívanie ICT odlišné ako v Českej republike, či na Slovensku.

\section{Literatúra}

[1] GORMAN, P., NELSON, T., GLASSMAN, A. (2004), The Millennial Generation: A Strategic oportunity. Organizational Analysis, Volume 12, Issue 3, p. 255-270. ISSN 1551-7470 [2] TAPSCOTT, D. (1997) Growing Up Digital: The Rise of the Net Generation. McGraw-Hill, Toronto.

[3] PRENSKY, M. (2001). Digital natives, digital immigrants. On the Horizont, Volume 9, Issue 5, p. 1-9. ISSN 1074-8121

[4] BENNETT S., MATON K., KERVIN L. (2008). The digital natives debate: a critical review of the evidence. British Journal of Educational Technology, Volume 39, Issue 5, p. 775-786. ISSN 0007-1013

[5] BROWN, C., CZERNIEWICZ, L. (2010). Debunking the 'digital native': beyond digital apartheid, towards digital democracy. Journal of Computer Assisted Learning,Volume 26, Issue 5, p. 357-369. ISSN 0266-4909

[6] BULLEN M., BELFER K., MORGAN T., QAYYUM A. (2008) The net generation in higher education: rhetoric and reality. International Journal of Excellence in ELearning, Volume 2, Issue 1, p. 1-13. ISSN 1996-871X

[7] LYSÁK, L. (2003). Globalisation versus glocalisation. Journal of Economics, Volume 51, Issue 8, p. 931-946. ISSN 0013-3035

[8] RETTIE, R. (2002). Net generation culture. Journal of Electronic Commerce Research, Volume 3, Issue 4, p. 254-264. ISSN 1389-5753 [9] WEILER, A. (2004). Information-seeking behavior in Generation Y students: motivation, critical thinking, and learning theory. The 
Journal of Academic Librarianship, Volume 31, Issue 1, p. 46-53. ISSN 0099-1333

[10] MONACO, M., MARTIN, M. (2007). The Millennial Student: A New Generation of Learners. Athletic Training Education Journal, Volume 2, Issue 2, p. 42-46. ISSN 1947-380X

[11] BORGES, N., MANUEL, S., ELAM, C. \& JONES, B. (2006). Comparing Millennial and Generation X medical students at one medical school. Academic Medicine, Volume 81, Issue 6, p. 571-576. ISSN 1040-2446

[12] BORGES, N. J., MANUEL. R.S., ELAM, C. L., JONES, B. J. (2010). Differences in motives between Millennial and Generation X medical students. Medical Education, Volume, 44, Issue 6 p. 570-576. ISSN 1365-2923

[13] ELAM, C., STRATTON, T., GIBSON, D. D. (2007). Welcoming a new generation to college: The millennial students. Journal of College Admission, Volume 195, Issue 2, p. 20 25. ISSN 0734-6670

[14] TWENGE, J. M. (2009). Generational changes and their impact in the classroom: Teaching generation me. Medical Education, Volume 43, Issue 5, p. 398-405. ISSN 1365-2923 [15] DJAMASBI, S., SIEGEL, M., TULLIS, T. (2010). Generation Y, web design, and eye tracking. International Journal of Human-
Computer Studies, Volume 68, Issue 5, p. 307323. ISSN 1071-5819

[16] JONES, C., HOSEIN, A. (2010). Profiling University Students' Use of Technology: Where is the Net Generation Divide? The International Journal of Technology, Knowledge and Society, Volume 6, Issue 3, p. 43-58. ISSN 1832-3669

[17] KERLINGER, F. N., LEE, H. B. (2000). Foundations of behavioral research (4th ed.). Forth Worth, TX: Hartcourt College Publishers. [18] SCHMIDT, C.E., MÖLLER, J., SCHMIDT, K., GERBERSHAGEN, M.U., WAPPLER, F., LIMMROTH, V., PADOSCH, S.A., BAUER, M. (2011). Generation Y. Anaesthesist, Volum 60, Issue 6, p. 517-524. ISSN 0003-2417

[19] SELWYN, N. (2009). The digital native myth and reality. Aslib Proceedings, Volume 61, Issue 4, p. 364-379. ISSN 0001-253X

\author{
PaedDr. Milan Kubiatko, Ph.D. \\ Katedra pedagogiky \\ Pedagogická fakulta MU \\ Poříčí 31 \\ 603 00, Brno, ČR \\ Tel: +420 549494885 \\ E-mail: mkubiatko@gmail.com \\ WWW pracoviště: \\ http://www.ped.muni.cz/wedu/index.php
}

